\title{
Corporate Governance, Family Ownership and Earnings Management: Emerging Market Evidence
}

\author{
Hümeyra Adıgüzel ${ }^{1}$ \\ ${ }^{1}$ Faculty of Economics and Administrative Sciences, Bahçeşehir University, İstanbul, Turkey \\ Correspondence: Hümeyra Adıgüzel, Faculty of Economics and Administrative Sciences, Bahçeşehir University, \\ İstanbul, Turkey. Tel: 90-212-381-5629. E-mail: humeyra.adiguzel@bahcesehir.edu.tr
}

Received: August 20, 2013

Accepted: September 9, 2013

Online Published: September 25, 2013

doi:10.5430/afr.v2n4p17

URL: http://dx.doi.org/10.5430/afr.v2n4p17

\begin{abstract}
Earnings management (EM) is particularly important for family-firms which are exposed to more severe type-II agency conflicts between minority and majority shareholders than non-family firms. This study investigates the effectiveness of independent boards, audit committees and the presence of an internal audit function (IAF) in monitoring and controlling EM in family-owned firms. Overall, the results suggest that total accruals management is lower in family-owned than in non-family-owned firms, but that there is no difference in the direction of accruals. Family ownership is also found to reduce the monitoring effectiveness of independent boards and IAFs regarding earnings management.
\end{abstract}

Keywords: Family-owned firms, Aggregate accruals, Type-II agency conflict, Board independence, Audit committee independence, Internal audit function

\section{Introduction}

Recently, although some studies have argued that family ownership is associated with higher earnings quality and firm performance (Ali, Chen, \& Radhakrishnan, 2007; Anderson \& Reeb, 2004; Wang, 2006), earnings management (EM) has become an important issue for family-controlled companies. Family firms certainly have less serious agency problems because of their reduced separation of ownership and management; however, they do have more serious agency problems between the controlling family and the minority shareholders (type-II agency problem).

Corporate governance mechanisms have received substantial scholarly attention as a way to reduce EM. There are a considerable number of studies (see for example Chang \& Sun (2010), Chtourou, Bedard, \& Courteau (2001), Jiang, Lee, \& Anandarajan (2008), Klein (2002), Larcker, Richardson, \& Tuna (2007), Xie, Davidson, \& DaDalt (2003) in the U.S; Baxter\& Cotter (2009), Davidson, Goodwin-Stewart, \& Kent (2005) in Australia; Peasnell, Pope, \& Young (2005) in the UK.; Bradbury, Mak, \& Tan (2006), Rusmin (2010), Saleh, Iskandar, \& Rahmat (2007), Siregar \& Utama (2008) in the Asian Countries) which document that the effectiveness of corporate governance mechanisms affect the EM practices of widely held public firms, however there are relatively less studies (Prencipe \& Bar-Yosef, 2011; Jaggi, Leung, \& Gul, 2009) which investigates whether the measures of corporate governance have the same effect on the level of EM when ownership is not widely dispersed, and in particular when ownership is concentrated in the hands of families.

This study contributes to the existing research by searching whether family ownership moderates the effectiveness of corporate governance mechanisms in reducing EM practices on a sample of Turkish firms. This is the first study investigating the EM made by family firms in Turkey. Turkey has an ideal setting to handle issues related to EM in family firms due to the presence of the large number of family firms among its listed companies. When we also consider the small and medium-sized enterprises owned by families besides the listed family firms, the total contribution of family firms to national income in Turkey is higher than 90 percent (Ankara Chamber of Industry, 2005). In Turkey, considering ultimate ownership rather than direct ownership, approximately all the publicly-held holding companies keep control over a large number of firms through a pyramidal structure. Families generally have control of the holding company, and have shareholdings in many other companies. On the other hand, in most cases, companies own shares hierarchically in each other under the holding company. (Demirag \& Serter, 2003; Yurtoğlu, 2003). Mitton (2002) suggests that legal protection deficiency over property rights provides firms some power to expropriate minority shareholder interests. In Turkey, there is inadequate protection of minority rights because of the 
underdeveloped equity culture of capital markets, the dominance of long term debt finance, and the inadequate legal environment.

La Porta, Lopez-de-Silanes, Shleifer, and Vishny (1998) argue that the primary conflict in a firm which is owned by a relatively few shareholders is between majority and minority shareholders because of the potential of the former to expropriate wealth from the latter. Especially in emerging markets such as Turkey (Note 1), where ownership is mostly in the hands of families and hence market control mechanisms are weak, corporate governance has to go beyond just solving agency problems between executives and shareholders. Rather it is important to solve conflict between ultimate shareholders who take an active role in the company (generally families) and minority shareholders and creditors.

This study first evaluates whether, in Turkey, Type-II agency problems between minority and majority shareholders outweigh the persistent Type I agency problems in family firms between shareholders and managers. It is conjectured that, if Type-II agency conflict dominates Type-I in family firms, income-decreasing EM will be higher than income-increasing EM. Ali et al. (2007) provide evidence for that prediction for US firms, where discretionary accruals are more negative for family firms than for non-family firms, which shows the dominance of income-decreasing accruals.

Second, this study examines whether family ownership reduces the monitoring effectiveness of independent boards in detecting and moderating EM in Turkish firms. It is conjectured that the existence of family ownership is likely to reduce the monitoring effectiveness of an independent corporate board as owning families have control over the appointment of board members and generally prefer to establish boards that do not try to alleviate their discretion over decision-making (Anderson \& Reeb, 2004; Chen \& Jaggi, 2000). Prior research has also provided evidence for that prediction (Prencipe \& Bar-Yosef, 2011; Jaggi et al., 2009).

This study then examines whether family ownership reduces the controlling effectiveness of independent audit committees on the level of EM. It is suggested that the existence of family ownership control in firms reduces the monitoring effectiveness of independent audit committees. Prior studies have generally evidenced that audit committee independence reduces the level of EM in publicly-listed widely held companies (Baxter \& Cotter, 2009; Chang \& Sun, 2010; Xie et al., 2003). However, there is one study (Jaggi \& Leung, 2007), to my knowledge, which provides evidence that the family-controlled Hong Kong firms were less likely to have audit committees focusing on EM when there are family members on corporate boards. This study thus extends the current literature by evaluating the effect of family ownership control on the effectiveness, rather than merely the presence, of independent audit committees in reducing the level of EM.

Finally this study evaluates whether family ownership reduces the monitoring effectiveness of a firm's internal audit function (IAF) on EM. Empirical research investigating the monitoring ability of an IAF on the opportunistic behaviors of managers is limited not only for family firms but also for widely-held companies. One prior study used archival data to investigate the effect of IAFs on EM, but found no evidence that the presence of an IAF is associated with a lower level of EM in widely-held companies (Davidson et al., 2005). Expanding the scope of Davidson's study, Prawitt, Smith, \& Wood (2009) have found evidence that high IAF quality is associated with a moderation of the level of EM. This study extends current literature by evaluating the effect of family ownership control on the monitoring effectiveness of an IAF on the level of EM.

This study consists of the firms traded on the Istanbul Stock Exchange (ISE) for the period 2006-2010. Content analyses of the yearly annual reports of all non-financial firms listed in the ISE for each reporting period between 2006 and 2010 were carried out to determine the internal corporate governance characteristics. Because of non-availability of required corporate governance data final sample includes 410 firm-year observations.

Following the broad operational definition used in many of the previous studies (Barnes \& Hershon, 1976; Carsrud, 1994; Gallo \& Sveen, 1991), in this study, companies in which one or more families linked by kinship, close affinity, or solid alliances hold a sufficiently large share of capital is assumed as family firms (Corbetta, 1995; Prencipe, Markarian, \& Pozza 2008) and hereafter stated as family-owned firms. In the study the magnitude of discretionary accruals is used as a proxy for EM. Discretionary accruals are measured by using the performance adjusted discretionary accruals model suggested by Kothari, Leone, and Wasley (2005).

The remainder of this article is organized as follows: The second part briefly describes the institutional environments and ownership structures of Turkish firms. The literature overview defines the family firms and considers the theoretical and empirical literature on corporate governance, agency costs and EM for family firms. Hypotheses are 
then developed based on the findings in the literature, and the methodology and data collection described. Finally, the results are presented and discussed, and conclusions drawn.

\section{Institutional Environments and Ownership Structures of Turkish Firms}

Corporate governance structure in Turkey can be classified as continental European-type, with long-term debt finance, ownership by large block-holders, weak markets for corporate control, and rigid labor markets. Publicly-held joint stock Turkish companies have highly concentrated and centralized ownership which is mainly achieved via pyramidal or complex structures and by using dual-class shares (Yurtoğlu, 2003). Turkish law does not have the one-share, one-vote principle, and Turkish companies can issue shares which has different cash-flow rights and different collateral rights in liquidation. Under Article 401 of the old Turkish commercial law, (Note 2) it was possible to issue non-voting shares and shares which had an arbitrarily high number of votes (Demirag \& Serter, 2003).

In Turkey, considering ultimate ownership rather than direct ownership, approximately all the publicly-held holding companies have control over a large number of firms through a pyramidal structure. Families ultimately own sixty-eight of the top ninety-four Turkish traded companies with an average ownership stake of 52.05 percent of the equity capital for the year end 1999 (Demirag \& Serter, 2003). More recent evidence of families' ultimate ownership of Turkish companies is provided by Yurtoğlu (2003). Of a sample of 305 companies listed on the ISE at the end of 2001, she analyzed the pyramidal ownership structures and the impact of dual-class shares and found that families controlled 242 of the 305 listed companies with an average 67 percent control rights of outstanding shares. Pyramidal structures are preferred in Turkey to raise external equity while retaining control in short leverage. These structures enable owners to keep ultimate majority control with controlling an unequal amount of cash flow rights (Demirag \& Serter, 2003).

\section{Literature Overview}

\subsection{Definition of a Family Firm}

Prior research provides evidence that family businesses are distinct from their non-family counterparts. Some studies exhibit that the family firms perform better than non-family- firms (Anderson \& Reeb, 2003; Beehr, Drexler, \& Faulkner, 1997; Daily \& Dolinger, 1992; Lee, 2006) while some show the reverse (Gallo, Tapies, \& Cappuyns, 2000; Gomez-Mejia, Nunez-Nickel, \& Gutierrez, 2001; Villalonga \& Amit, 2004; Klein, Shapiro, \& Young, 2005). To understand the mixed results of studies about family businesses, it is important to clearly define what a family firm is. The literature provides several different operational definitions of family firms which focus on some combinations of components of families' involvement in the business (Chrisman, Chua, \& Sharma, 2005). Besides these operational definitions, there are two dominant theoretical approaches to the definition of family firms (Siebels \& Knyphausen-Aufseb, 2011): the components-of-involvement approach and the essence approach (Chua, Chrisman, \& Sharma, 1999). According to the components-of-involvement approach, it is a sufficient condition that some kind of family involvement exists, such as ownership, management, or governance to be considered as a family firm (Chua et al. 1999; Chrisman et al 2005). The important problem associated with this approach is that in some cases companies which have same level of family involvement in ownership and management may not consider themselves family firms and may not behave as family businesses. Therefore, the essence approach requires that family involvement must be directed toward behaviors that provide distinctiveness before a company can be considered a family firm (Chrisman et al 2005).

\subsection{Corporate Governance, Agency Costs, and EM in Family-owned Firms}

Agency theory is a dominant theoretical framework in family firm governance studies, and it has been broadly applied in the area of family business and corporate governance (Siebels \& Knyphausen-Aufseb, 2011). Considering family businesses, there are two opposite views about the level of agency costs. On the one hand, some researchers theorize that family firms are exempt from the problem of agency because of their altruistic, intra-familial element (Jensen \& Meckling, 1976; Daily \& Dollinger, 1992). The logic behind Jensen and Meckling's claim is that management by the owner eliminates agency costs because most agency costs are caused by conflicts that arise from the seperation of ownership and control (Type I agency conflict). On the other hand, family firms may be exposed to more agency costs than their non-family counterparts because of 1) altruistic behavior, and 2) management entrenchment and shareholder expropriation (Schulze, Lubatkin, Dino \& Buchholz, 2001).

In parallel with the two opposite views of agency costs in family-controlled firms, there are also two opposing theoretical viewpoints related with the impact of family ownership control on EM. In the first view, family control reduces the level of EM. The US-based studies of Jiraporn and Dadalt (2007) and Wang (2006) and the Italy-based study of Prencipe and Bar-Yosef (2011) all provide empirical evidence that the level of abnormal accruals is lower 
for family firms than for their non-family counterparts. These findings suggest that the founding families' long tenure in the company causes them to focus more on the long term and limit the fears of management to meet short-term earnings expectations. Additionally, their long tenure provides the firm-specific knowledge, enabling them to better monitor management.

Although family ownership control moderates the agency conflict between managers and shareholders (Type I agency conflict), it causes a conflict between controlling shareholders (generally families) and minority shareholders (Type II agency conflict). The replacement of one type of agency problem with another has important meanings for family firms. The positive impact of eliminating Type-1 agency conflict may be outweighed by the negative impact caused by management entrenchment (Bhaumik \& Gregoriou, 2010). There is a likelihood of EM for firms in which ownership is mostly held by blockholders like families (Fan \& Wong, 2002), and the peculiar governance characteristics of family firms enable easy expropriation of non-family shareholders. One of the major governance characteristics of family firms is the close relationship between family members and managers; in most family firms managers are either members of the controlling family or linked to it by close personal relations. This close relationship may direct managers to manage earnings toward the goals of the controlling family at the expense of the wealth of minority shareholders.

\section{Hypothesis Development: Corporate Governance and EM in Family-owned Firms}

\subsection{EM in Family-owned Firms}

As discussed earlier, non-family-owned firms have more serious Type I agency problems than family-owned firms due to the separation of ownership and management. There are many incentives for managers to manipulate earnings opportunistically for their own welfare. Executive compensation schemes which tie managers' incentives to company performance may encourage managers to manipulate accounting numbers (Bergstresser \& Philippon, 2006; Cheng \& Warfield, 2005; Guidry, Leon, \& Rock, 1999; Healy, 1985; Holthausen, Larcker, \& Sloan, 1995; Iatridis \& Kadorinis, 2009; Shuto, 2007). Additionally, managers may opportunistically manipulate earnings to meet particular benchmarks, such as zero earnings (avoiding losses), prior period earnings (avoiding earnings decreases) and analysts' forecasts (Bartov, Givoly, \& Hayn, 2000; Barua, Legoria \& Moffitt, 2006; Burgstahler \& Eames, 2006; Choi \& Lin, 2006; Kasznik, 1999; Kasznik \& McNichols, 2002; Matsumoto, 2002; Matsunaga \& Park, 2001). Another incentive to manipulate earnings is debt covenants; managers are more likely to prefer accounting procedures that shift reported earnings from future periods to the current period when the firm is closer to violation of accounting-based debt covenants (Bartov, 1993; DeFond \& Jiambalvo, 1994; Iatridis \& Kadorinis, 2009; Sweeney, 1994). Finally, in firms about to go public, managers may also manage earnings to increase current earnings before initial public offerings (IPO) and seasoned equity offerings (SEO) in the hope of receiving a higher price for their shares (Aharoni, Wang, \& Yuan, 2010; Cohen \& Zarowin, 2010; Cormier \& Martinez, 2006; Friedlan, 1994; Jackson, Wilcox, \& Strong, 2002; Shivakumar, 2000; Teoh, Welch, \& Wong, 1998a; Teoh, Welch, \& Wong, 1998b). Most of these manipulations are achieved through income-increasing accruals that shift reported earnings from future periods to the current period. Although factors such as legal liabilities and reputation concerns in the labor market help reduce Type I agency problems, they do not totally eliminate them. On the other hand, family-owned firms are exposed to more serious Type II agency problems because of families' majority ownership patterns and significant control over firm management. This causes managers to manipulate earnings through income-decreasing accruals to meet the long-term expectations of family members rather than to achieve short-term goals. The desire to reduce political costs or minimize tax may motivate family-owned firms to generate negative accruals(Ali et al., 2007). It can thus be assumed that, on average, the managers of family-owned firms have both incentives to increase income through income-increasing accruals because of a persistent Type I agency conflict as well as incentives to decrease income through income decreasing accruals as a result of a Type II agency conflict. Prencipe et al. (2008) provide empirical evidence that the incomplete elimination of Type I agency conflict in publicly-listed family companies, showing that managers are still motivated to manage earnings for debt-covenant and leverage-related reasons.

It is conjectured that if Type II agency problems dominate Type I agency problems in a family-owned firm, discretionary accruals will be more negative compared to those in non-family-owned firms, which will shows less opportunistic behaviors by managers. The following hypothesis is developed to test this expectation:

Hypothesis 1: There is a significant difference between the direction of abnormal accruals of family-owned firms and non-family-owned firms. 


\subsection{Elements of Internal Corporate Governance and Testable Hypothesis}

The accounting policies which are a part of firm's overall need to minimize its cost of capital and contracting costs are largely determined by the firm's organizational structure and are a part of the overall process of corporate governance (Scott, 2006). The corporate governance model developed by the Institute of Internal Auditors (IIA) specifies four cornerstones of effective corporate governance; the audit committee of the board of directors, executive management, internal audit function, and the external auditor (IIA 2005).

\subsubsection{The Board of Directors and EM in Family-owned Firms}

The role of the board of directors in corporate governance is to monitor managers' performance when conducting business to the benefit of shareholders. It is expected that the more independent the board of directors is, the less earnings manipulation will be possible for the managers (Chtourou et al., 2001; Davidson et al., 2005; Osma, \& Naguer, 2007; Peasnell et al., 2005). However, considering family businesses, there arise some specific and characteristic agency issues, such as the owning family's pursuit of its own economic interests; its pursuit of its own non-economic interests; the parental tendency to act upon altruistic motives; and the different nuclear family units' pursuit of their own interests (Bammens, Voordeckers, \& Gils, 2011). These issues may present barriers to the independent board's monitoring effectiveness in reducing EM practices. In most of the family-owned firms, the families generally prefer to establish boards that do not try to alleviate their discretion over decision-making (Anderson \& Reeb 2004; Chen \& Jaggi 2000). This may reduce the ability of boards to curtail the activities of managers who are generally family members or have close relationships with the owning family, and who may try to manage earnings toward the goals of the controlling family at the expense of minority shareholders. Based on this prediction, it is expected family control through family ownership concentration reduces the monitoring effectiveness of independent boards. The following hypothesis is developed to test this expectation:

Hypothesis 2: Independent boards of directors are less effective to monitor EM in family-owned firms compared to non-family-owned firms.

\subsubsection{Audit Committees and EM in Family-owned Firms}

In the last few decades, the importance and role of audit committees in the quality of financial reporting have received substantial attention from academics and regulators, and there have been corporate governance pronouncements, such as the Cadbury Committee (1992) in the UK and the Blue Ribbon Committee (1999) in the U.S.

In the corporate governance mechanism, the audit committee represents the board and enables personal contact and communication between the board, internal auditors, external auditors, the finance director and the operating executives (Song \& Windram, 2004). The essential role of the audit committee is to monitor financial reporting, and it behaves as a final protection in approving the financial statements prior to their release to shareholders and other stakeholders. Therefore, an independent audit committee is expected to reduce the opportunistic and self-interested manipulation of financial information by managers, and previous studies have provided evidence for this prediction (Baxter \& Cotter, 2009; Chang \& Sun, 2010; Xie et al., 2003).

Because the audit committee is a sub-committee of the corporate board, the same agency issues specific to the boards of family-owned firms are also a problem for their audit committees. The owning-family's pursuit of its own interests and altruistic behaviors may affect the regular assembly of the audit committee, and this may prevent the efficient detection of managerial opportunism by the committee. Based on this prediction, it is expected family control through family ownership concentration reduces the monitoring effectiveness of independent audit committees. The following hypothesis is developed to test this expectation:

Hypothesis 3: Independent audit committees are less effective to monitor EM in family-owned firms compared to non-family-owned firms.

\subsubsection{Internal Audit Function and EM in Family-owned Firms}

The important monitoring role of the Internal Audit Function (IAF) has received much attention from academics and regulators as an important contributor to effective corporate governance. Agency theory provides a framework to express the demand for internal auditing and recommends a monitoring role for the internal audit.

The IAF is the only party which is responsible for the day-to-day implementation, testing, and monitoring of the actions of management, and so has the potential to affect a company's external financial reporting (Prawitt et al., 2009). Although the IAF may be effective in reducing EM practices, this relationship has not been extensively examined in the literature. One prior effort which uses archival data to examine the effect of IAFs on EM found no 
evidence that the presence of an IAF is associated with a lower level of EM (Davidson et al., 2005). Expanding on the scope of the Davidson's study, Prawitt et al., (2009) has found evidence that high IAF quality moderates the level of EM. However, empirical research investigating the monitoring ability of an IAF on the opportunistic behaviors of managers in family businesses is limited.

Acknowledging that the internal audit department reports to the audit committee, which is a sub-committee of the board, and that, in most family-owned firms, owning-families generally, prefer to establish cooperative boards. As a result of weak monitoring by internal audit functions of family-owned firms, presence of IAF is not related with the level of EM in family-owned firms. The following hypothesis is developed to test this expectation:

Hypothesis 4: The presence of an IAF is negatively related to the level of EM in non-family-owned firms, but is unrelated to the level of EM in family-owned firms.

\section{Sample Selection}

The empirical analysis was carried out using a Turkish data set. Under Turkish Disclosure rules, publicly-held joint stock companies have been required to declare the "Corporate Governance Compliance Reports" in their annual reports since 2004. Content analyses of the yearly annual reports of all non-financial firms listed in the ISE were carried out for each of the five reporting period between 2006 and 2010. Unfortunately, not all companies disclosed the full set of corporate governance data needed for the empirical analysis. After excluding the companies that didn't provide the necessary information for the analysis, the sample consisted of 93 firms. The sample was then divided according to industry due to the method used in measuring EM; for the calculations, each industry had to include at least 8 firms. After the elimination of firms belonging to industries which did not support the minimum number requirement, the final sample consists of eighty-two firms (seventy-four manufacturing and eight technology) and 410 firm-year observations. Table 1 illustrates the derivation of the sample.

Table 1. Derivation of Sample

\begin{tabular}{l|c}
\hline Description & $\underline{\text { Sample Size }}$ \\
\hline Total Numbers of Firms Listed In ISE Between The Years 2005 To 2010: & 262 \\
Less: Financial Institutions: & $\underline{74}$ \\
Less: The Number of Firms Which All of the Annual Reports Between Years 2005 to 2010 & $\underline{56}$ \\
Has Not Been Found. & \\
Less: The Firms Which Has No Required Corporate Governance Data in the Compliance & \\
Reports. & $\underline{39}$ \\
Less: The Firms which belongs the industry which does not have the required numbers of & $\underline{11}$ \\
firms. & 82 \\
Firms Available for Final Sample & \\
\hline
\end{tabular}

Once the sample was selected, the family-owned firms were distinguished from the non-family ones. In this study, the ultimate shareholders of the firms were determined by analyzing the pyramidal ownership structures, and firms were assumed to be family-owned when a family was the biggest shareholder. Information demonstrating these pyramidal structures was obtained from Turkey's Public Disclosure Platform (kap.gov.tr). By this methodology, of the eighty-two firms in the sample, thirty-six were determined to be family-owned firms.

\section{Results}

\subsection{Discretionary Accruals}

In the present study, discretionary accruals are estimated from the performance-adjusted cross-sectional variation of the modified John's model (Kothari et al., 2005). For each year and for each industry group, total accruals are modeled as a function of change in revenues adjusted for the change in receivables, the level of plant, property and equipment, and Return on Asset using the following cross-sectional OLS regression model.

$$
\mathrm{TA}_{\mathrm{it}} / \mathrm{A}_{\mathrm{it}-1}=\beta 0+\alpha \mathrm{i}\left[1 / \mathrm{A}_{\mathrm{it}-1}\right]+\beta_{1 \mathrm{i}}\left[\left(\Delta \mathrm{REV}_{\mathrm{it}}-\Delta \mathrm{AR}_{\mathrm{it}}\right) / \mathrm{A}_{\mathrm{it}-1}\right]+\beta_{2 \mathrm{i}}\left[P P E_{i t} / A_{i t-1}\right]+\beta_{3 \mathrm{i}} \mathrm{ROA}_{\mathrm{it}(\text { or it-1) }}+\varepsilon_{\mathrm{it}}
$$

where;

$\mathrm{TA}_{\mathrm{it}}=$ total accruals in year $t$ for firm $i$;

$\Delta \mathrm{REV}_{\mathrm{it}}=$ revenues in year $t$ less revenues in year $t-1$ for firm $i$;

$\Delta \mathrm{REC}_{\mathrm{t}}=$ net receivables in year $\mathrm{t}$ less net receivables in year $\mathrm{t}-1$; 
$P P E_{i t}=$ gross property, plant, and equipment in year $t$ for firm $i$;

$\mathrm{ROA}_{\mathrm{it}}=$ return on asset in year $\mathrm{t}$ for firm $\mathrm{i}$;

$A_{i t-1}=$ total assets in year $t-1$ for firm $i$;

$\varepsilon_{\mathrm{it}}=$ error term in year $t$ for firm $i$;

$i=$ firm index;

$t=$ year index for the years included in the estimation period for firm $i$.

The model is applied to the two industry groups of seventy-four manufacturing and eight technology firms separately for each year from 2006 to 2010. This model estimates parameters for predictive purposes rather than testing the statistical significance of parameters. The coefficients obtained from the above equation are used to determine firm-specific non-discretionary accruals, and discretionary accruals are obtained as the difference of total accruals and non-discretionary accruals.

Unlike Dechow, Sloan, and Sweeney (1995), the current study assumes that changes in accounts receivable are unmanaged and that observable changes arise from EM (Kothari et al., 2005). Dechow et al. (1995) assume that sales are not managed in the pre-event period, and the change in accounts receivable in the event year is due to EM. Because the current study does not have a pre-event period, the equation in which the parameters are determined is also modified for the effects of changing levels of accounts receivable (Kothari et al., 2005). In the study, the cash flow approach is used to determine total accruals (Davidson et al., 2005; Klein, 2002; Larcker et al., 2007; Prawitt et al., 2009) as the difference between the net income before extraordinary items and cash flow from operations, which is obtained from the statement of cash flows.

The following models are designed to examine the relationship between the absolute and directional values of discretionary accruals, as well as whether a firm is family-owned or non-family-owned, after controlling for the effects of other variables discussed in the literature for their relevance to EM.

$$
\begin{aligned}
& \text { ABSAbbAcc }_{i t}=\beta_{0}+\beta_{1} \text { PFamilyFirm } \beta_{2} \text { Assets }_{i t}+\beta_{3} \text { Leverage }_{i t}+\beta_{4} \text { SGrowt }_{i t}+\beta_{5} \text { ROA }_{i t}+\beta_{6} \text { Loss }+\varepsilon \\
& \text { AbbAcc }_{i t}=\beta_{0}+\beta_{1} \text { PFamilyFirm } \beta_{2} \text { Assets }_{i t}+\beta_{3} \text { Leverage }_{i t}+\beta_{4} \text { SGrowth }_{i t}+\beta_{5} \text { ROA }_{i t}+\beta_{6} \text { Loss }+\varepsilon
\end{aligned}
$$

In the first model, the dependent variable is $A B S A b b A c c$, which is the absolute value of performance adjusted discretionary accruals. In the second model, the dependent variable is $A b b A c c$, which shows the negative and positive abnormal accruals.

The independent variable is PFamilyFirm, which is the predicted value of family ownership. Following prior studies which suggest that concentrated ownership by families and performance of firm may be endogenously determined (Jaggi et al., 2009; Anderson \& Reeb, 2003), first family ownership is regressed with the natural log of total assets and $R O A$ (return on asset) to obtain the predicted value of family ownership. Other variables are defined as follows: Assets is the natural log of total assets. There are two opposite views about the sign of this variable. The first suggests that big firms with a high chance of receiving political attention are more likely to manipulate earnings to avoid political scrutiny (Jeong \& Rho, 2004), and some studies evidence that asset size correlates positively with abnormal accruals (Dechow \& Dichev, 2002; Chtourou \& Bedard, 2001; Prawitt et al., 2009). The second view suggests that larger firms are more visible so are less likely to manage earnings (Chen, Lin, \& Zhou, 2005), and other studies' findings support this prediction (Davidson et al., 2005; Wang, 2006). Another control variable, Leverage, is measured as total debt divided by total assets. DeFond and Jiambalvo (1994) and Iatridis and Kadorinis (2009) provide evidence that managers manipulate earnings to avoid getting close to debt covenants, and this variable is widely used in EM studies (Peasnell et al., 1998; Klein, 2002; Park \& Shin, 2004; Davidson et al., 2005; Chen et al., 2005; Carcello et al., 2006; Prawitt et al., 2009; Baxter et al., 2009; Chang \& Sun, 2010). Matsumoto (2002) claims that managers of high-growth firms have major incentives to avoid missing earnings expectations, creating an extra incentive for them to manage earnings. Consistent with Prawitt et al. (2009), this study controls for the effects of sales growth on EM. SGrowth measures the one-year sales growth of firms. ROA is included to control for potential changes in firm performance. This is because prior research provides evidence that measurement of discretionary accruals can be a problem for firms which have extreme financial performance (Dechow et al., 1995; Kothari et al., 2005). Following prior studies, Loss is also added as a control variable to clarify managers' incentive to avoid losses (Chen et al., 2005; Prawitt et al., 2009; Baxter, 2009). Burgstahler and Dichev (1997) state that firms manage reported earnings to avoid reporting earnings decreases and losses. 
Table 2. Discreationary Accruals and Family-owned Firms

\begin{tabular}{lcccccc}
\hline Regression Estimates & \multicolumn{5}{c}{} \\
\hline & \multicolumn{7}{c}{ Dependant Variable= ABSAbbAcc } & \multicolumn{2}{c}{ Dependant Variable= AbbAcc } \\
\cline { 2 - 7 } & $\begin{array}{c}\text { Expected } \\
\text { sign }\end{array}$ & Coefficient & t-stat & $\begin{array}{c}\text { Expected } \\
\text { sign }\end{array}$ & Coefficient & t-stat \\
\hline Intercept & & -0.1733 & -1.49 & & 0.1502 & 1.34 \\
PFamilyFirm & & -0.3180 & $-3.05^{* *}$ & & 0.0362 & 0.35 \\
Assets & & 0.0196 & $2.47^{* *}$ & & -0.0085 & -1.16 \\
Leverage & & 0.0478 & $4.59^{* * *}$ & & -0.0182 & -1.15 \\
SGrowth & & 0.0002 & 0.92 & & 0.0003 & 1.18 \\
ROA & & -0.1036 & -1.21 & & 0.2711 & $3.94 * * *$ \\
Loss & & 0.0077 & 0.43 & & -0.0129 & -0.72 \\
R-square (between) & 0.2037 & & & 0.4161 & & \\
Prob $>$ Chi ${ }^{2}$ & 0.0001 & & & 0.0000 & & \\
Number of observations & 410 & & & 410 & & \\
\hline
\end{tabular}

The reported t-statistics are robust values to control for heteroskedasticity.

ABSAbbAcc $=$ Absolute value of discreationary accruals

AbbAcc $=$ Directional values of discreationary accruals

PFamilyFirm= Predicted value of regressing family ownership on the natural log of total assets and ROA.

Assets $=$ The natural $\log$ of total assets

Leverage $=$ Total debt divided by total assets

Sgrowth $=$ One year sales growth

$\mathrm{ROA}=$ Return on Asset

Loss $=$ Dummy variable takes the value of 1 if net income is less than zero firm $\mathrm{i}$ in year $\mathrm{t}, 0$ otherwise.

$*, * *, * * *$ Denote Significance at the $0.1,0.05$ and 0.001 level respectively.

Table 2 reports the regression estimates of the equations. The coefficient on PFamilyFirm is significant for ABSAbbAcc model $(-0.3180, \mathrm{t}=-3.05)$. This result is consistent with previous studies of Italy (Prencipe and Bar-Yosef, 2011) and the US (Jiraporn and Dadalt, 2007; Wang, 2006) which find that the absolute value of abnormal accruals is lower for family firms. However, this study finds no significant difference between the sign of the discretionary accruals of family-owned firms and non-family-owned firms. The coefficient on PFamilyFirm is insignificant for the AbbAcc model (0.0362, $\mathrm{t}=0.35)$. In the case of directional abnormal accruals, the findings are not consistent with the US-based study by Ali et al. (2007), which shows that discretionary accruals are more negative for family firms than for non-family firms. Overall, the results suggest that, in Turkish family-owned firms, total accrual management is lower in family-owned firms compared to non-family-owned firms, but that, in family-owned firms, income-decreasing accruals resulting from Type II agency conflict do not dominate income-increasing accruals resulting from Type I agency conflict.

\subsection{Corporate Governance and EM in Family-owned Firms}

\subsubsection{Descriptive Statistics}

Table 3 presents descriptive statistics of the data. First, although it was stated previously that the large majority of listed companies in ISE are family-owned firms, note that just 44 percent of the full sample is composed of family-owned firms. Because the sample includes only firms with full disclosure of corporate governance data, most family-owned firms were eliminated because such data was unavailable. Ali et al. (2007) provide evidence that family firms tend to report less information about their corporate governance practices. 
Table 3. Descriptive Statistics

\begin{tabular}{|c|c|c|c|c|c|c|c|c|c|}
\hline \multicolumn{5}{|c|}{ Panel A: Descriptive Statistics of Full Sample } & \multicolumn{5}{|c|}{ Panel B: Comparison of Statistics of Two Sub samples } \\
\hline & \multicolumn{4}{|c|}{ Full Sample } & \multicolumn{3}{|c|}{ Mean } & \multicolumn{2}{|c|}{ Std. Dev. } \\
\hline & Mean & $\begin{array}{l}\text { Std. } \\
\text { Dev. }\end{array}$ & Min. & $\operatorname{Max}$. & $\begin{array}{c}\text { Family- } \\
\text { Owned } \\
\text { firms }\end{array}$ & $\begin{array}{l}\text { Non-Family- } \\
\text { Owned firms }\end{array}$ & t-stat & $\begin{array}{c}\text { Family- } \\
\text { Owned } \\
\text { firms }\end{array}$ & $\begin{array}{l}\text { Non-Family- } \\
\text { owned firms }\end{array}$ \\
\hline BoardInd & 0.80 & 0.39 & 0 & 1 & 0.78 & 0.81 & 0.60 & 0.41 & 0.39 \\
\hline ACInd & 0.85 & 0.35 & 0 & 1 & 0.83 & 0.86 & 1.02 & 0.37 & 0.33 \\
\hline$I A F$ & 0.46 & 0.49 & 0 & 1 & 0.52 & 0.42 & $-2.01 * *$ & 0.50 & 0.49 \\
\hline BoardMeet & 22.3 & 12 & 2 & 93 & 22.13 & 22.58 & 0.37 & 10.87 & 12.87 \\
\hline ACSize & 2.16 & 0.45 & 1 & 4 & 2.15 & 2.18 & 0.71 & 0.43 & 0.47 \\
\hline ACTimeCom & 0.92 & 0.25 & 0 & 1 & 0.9 & 0.95 & $2.05^{* *}$ & 0.30 & 0.21 \\
\hline Big4 & 0.52 & 0.50 & 0 & 1 & 0.64 & 0.43 & $-4.18 * * *$ & 0.48 & 0.49 \\
\hline ConcOwner & 0.63 & 0.17 & 0.12 & 0.99 & 0.64 & 0.63 & -0.93 & 0.15 & 0.19 \\
\hline ForeignInv & 0.25 & 0.43 & 0 & 1 & 0.29 & 0.23 & -1.24 & 0.45 & 0.42 \\
\hline Assets & 19.41 & 1.40 & 15.88 & 22.71 & 19.69 & 19.18 & $-3.69 * * *$ & 1.49 & 1.29 \\
\hline Leverage & 0.47 & 0.46 & 0.02 & 4.13 & 0.52 & 0.44 & -1.59 & 0.57 & 0.35 \\
\hline Sgrowth & 17.53 & 107.50 & -99.62 & 1593.2 & 22.68 & 13.50 & -0.85 & 141.46 & 70.43 \\
\hline$R O A$ & 0.029 & 0.196 & -2.88 & 1.005 & 0.026 & 0.031 & 0.24 & 0.14 & 0.22 \\
\hline Loss & 0.26 & 0.44 & 0 & 1 & 0.283 & 0.25 & -0.70 & 0.45 & 0.43 \\
\hline
\end{tabular}

Panel C: Proportions of Variables within Sub samples

\begin{tabular}{|c|c|c|c|}
\hline & & Family-owned firms & Non-Family-Owned firms \\
\hline \multirow[t]{2}{*}{ BoardInd } & Comprised of majority of non-executive directors & 0.79 & 0.81 \\
\hline & Comprised of majority of executive directors & 0.21 & 0.19 \\
\hline \multirow[t]{2}{*}{ ACInd } & Comprised of majority of non-executive directors & 0.83 & 0.87 \\
\hline & Comprised of majority of executive directors & 0.17 & 0.13 \\
\hline \multirow[t]{2}{*}{$I A F$} & Have an IAF & 0.52 & 0.42 \\
\hline & Do not have an IAF & 0.48 & 0.58 \\
\hline \multirow[t]{2}{*}{ AC TimeCom } & Serve in more than one committee & 0.10 & 0.05 \\
\hline & Do not serve in more than one committee & 0.90 & 0.95 \\
\hline \multirow[t]{2}{*}{ Big4 } & Audited by a Big4 & 0.64 & 0.43 \\
\hline & Audited by an Auditing Firm other than Big4 & 0.36 & 0.57 \\
\hline \multirow[t]{2}{*}{ Loss } & Experienced a Loss & 0.28 & 0.25 \\
\hline & Do not experienced a loss & 0.72 & 0.75 \\
\hline \multirow[t]{2}{*}{ ForeignInv } & Owned by an institutional foreign investor & 0.29 & 0.23 \\
\hline & Do not owned by an institutional foreign investor & 0.71 & 0.77 \\
\hline
\end{tabular}

Panel B of table 3 reports the comparison of statistics of family-owned and non-family-owned sub-samples. The variables $I A F, B i g 4$, and Assets are significantly higher for family-owned firms. For all other variables, there is no significant difference between family-owned and non-family-owned firms.

\subsubsection{Regression Results}

The following model is estimated to examine the effect of board independence, audit committee independence, and the presence of an internal audit function on the level of discretionary accruals.

$$
\begin{gathered}
\text { ABSAbbAcc }{ }_{i t}=\beta_{0}+\beta_{1} \text { BoardInd }_{\mathrm{it}}+\beta_{2} \text { ACInd }_{\mathrm{it}}+\beta_{3} \text { IAF }_{\mathrm{it}}+\beta_{4} \text { BoardMeet }_{\mathrm{it}}+\beta_{5} \text { ACTimeCom }+\beta_{6} \text { ACSize } \\
\mathrm{it}
\end{gathered}
$$

In model 1, the dependent variable is $A B S A b b A c c$, which is the absolute value of performance-adjusted discretionary accruals. The absolute value of discretionary accruals is used rather than directional values because the study has previously found no difference between the directions of discretionary accruals of family- and non-family-owned firms. The first independent variable is BoardInd, a dummy variable which takes the value 1 if the firm's board of directors is comprised of a majority of non-executives, otherwise 0. Following prior research (Davidson et al., 2005; Baxter \& Cotter, 2009) and the recommendation of the Capital Market Board of Turkey (CMB), the present study measures the independence of the board of directors by whether the majority of directors are non-executives. The second independent variable is ACInd, which takes the value 1 if the committee is comprised of a majority of 
non-executive directors, otherwise 0. The Corporate Governance Principles of Turkey's CMB require that each committee should comprise at least two members and, if there are only two members, both of them should be non-executive members. If there are more than two members in a committee, the majority of members should be non-executive members. The third independent variable of the model is $I A F$, which takes the value 1 if the company has a separate IAF, otherwise 0 .

Following prior research, some control variables related to the governance structures of firms have been added to the model. BoardMeet is the number of board meetings held annually by the board of directors. Prior studies assume that if a board meets more often it should have more time to discuss special issues and be more capable of controlling managers' discretionary behaviors (Carcello et al., 2006; Xie et al., 2003; Baxter et al., 2009). CMB principles require that the members of the board of directors cannot be assigned to more than two committees. To control for this requirement, the current study measures the multiple time commitments of audit committee members (ACTimeCom) by whether committee members serve on more than one committee. ACSize is another control variable. The CMB recommends that the board should establish an audit committee with at least two members. Following prior research (Davidson et al., 2005; Baxter et al., 2009; Felo, Krishnamurthy, \& Solieri, 2003; Xie et al., 2003), the current study measures audit committee size simply by the numbers of audit committee members. Again following prior studies (Chtourou \& Bedard, 2001; Jeong \& Rho, 2004; Davidson et al., 2005; Chen et al., 2005; Carcello et al., 2006; Piot \& Janin, 2007; Baxter \& Cotter, 2009; Chang \& Sun, 2010), the current study uses Big4 as a control variable which takes the value of 1 if the firm is audited by one of the "big four" auditing firms, otherwise 0 . The study controls for the effects of large block holders and measures ConcOwner as the percentage of shares held by the largest three substantial shareholders with more than 5 percent of the shares. Jensen (1993) states that large block shareholders have incentives to monitor management and serve as an additional control mechanism. This study also controls for the effects of foreign institutional investors by assuming that they are a control mechanism reducing discretionary behaviors by the managers. Their presence is measured by the variable ForeignInv, which takes the value of 1 if company has institutional foreign investor, 0 otherwise.

Table 4. Pearson (Top) and Spearman (Bottom) Correlations Coefficients among the Variables

\begin{tabular}{|c|c|c|c|c|c|c|c|c|c|c|c|c|c|c|}
\hline & ACInd & ACSize & ACTimeCom & BoardInd & BoardMeet & $I A F$ & $B I G 4$ & Assets & Leverage & SGrowth & $R O A$ & Loss & ConcOwner & ForeignInv \\
\hline ACInd & & -0.0741 & 0.0473 & $0.6091^{* *}$ & 0.0473 & $0.2445^{* *}$ & $0.3657^{* *}$ & $0.2955^{* *}$ & $-0.1631^{*}$ & -0.0276 & 0.0460 & $-0.1257^{*}$ & $0.3743^{* *}$ & 0.0869 \\
\hline ACSize & $-0.1243^{*}$ & & -0.0025 & 0.0487 & -0.0711 & 0.0128 & $-0.1197^{*}$ & 0.0847 & $0.1232^{*}$ & -0.0222 & 0.0488 & -0.0888 & -0.0425 & 0.3316 \\
\hline ACTimeCom & 0.0473 & -0.0011 & & -0.0174 & 0.0446 & -0.0121 & 0.0420 & 0.0328 & -0.0129 & 0.0429 & 0.0083 & -0.0278 & -0.0573 & -0.0761 \\
\hline BoardInd & $0.6091^{* *}$ & 0.0246 & -0.0174 & & $0.1007 *$ & $0.2254 * *$ & $0.3002 * *$ & $0.2569 * *$ & $-0.2606 *$ * & -0.0834 & $0.1499^{*}$ & $-0.1313^{*}$ & $0.3769 * *$ & 0.0691 \\
\hline BoardMeet & 0.0254 & -0.0420 & 0.0467 & 0.0794 & & $0.0981^{*}$ & 0.0604 & 0.0934 & -0.0766 & -0.0298 & -0.0002 & $0.1015^{*}$ & $-0.1070^{*}$ & $-0.2788^{* *}$ \\
\hline IAF & $0.2445^{\star * \pi}$ & 0.0270 & -0.0121 & $0.2254^{* *}$ & 0.0580 & & $0.1949^{\text {** }}$ & $0.3267^{* * *}$ & -0.0572 & -0.0336 & -0.0155 & -0.0581 & $0.2178^{* *}$ & $0.1468^{*}$ \\
\hline BIG4 & $0.3657^{* *}$ & $-0.1293^{*}$ & 0.0420 & $0.3002^{* *}$ & 0.0414 & $0.1949 * *$ & & 0.3321 ** & $-0.1691^{* *}$ & -0.0222 & $0.1067^{*}$ & $-0.1123^{*}$ & $0.3847^{* *}$ & 0.0158 \\
\hline Assets & $0.2985^{\star *}$ & $0.1106^{*}$ & 0.0295 & $0.2330^{* *}$ & $0.1074^{*}$ & $0.3030^{* *}$ & $0.3145^{* \star}$ & & $-0.1141^{*}$ & 0.0075 & $0.1920^{* *}$ & $-0.3171^{* *}$ & $0.2711^{* *}$ & $0.1767^{* *}$ \\
\hline Leverage & 0.0413 & -0.0025 & 0.0142 & -0.0833 & $-0.1383^{*}$ & 0.0594 & -0.0775 & -0.0467 & & 0.0024 & $-0.4459^{* *}$ & $0.3385^{* *}$ & -0.0928 & -0.0495 \\
\hline SGrowth & 0.0391 & 0.0362 & 0.0964 & 0.0500 & 0.0401 & 0.0838 & -0.0194 & 0.0938 & 0.0158 & & 0.0104 & -0.0445 & -0.0353 & -0.0511 \\
\hline$R O A$ & $0.1152^{*}$ & 0.0950 & 0.0500 & $0.1381^{*}$ & -0.0543 & 0.0446 & $0.1319^{*}$ & $0.2730^{\text {** }}$ & $-0.5395^{* *}$ & $0.2345^{\text {** }}$ & & $-0.4922 * *$ & 0.0544 & 0.0018 \\
\hline Loss & -0.1257 & -0.1049 & -0.0278 & $-0.1313^{*}$ & 0.0878 & -0.0581 & $-0.1123^{\star}$ & $-0.3070^{* *}$ & $0.3838^{* *}$ & $-0.2025^{* *}$ & $-0.7652^{* *}$ & & $-0.1236^{*}$ & $0.3718^{* *}$ \\
\hline ConcOwner & $0.3720^{* *}$ & -0.0520 & -0.0542 & $0.3506^{* *}$ & -0.0875 & 0.1761 ** & $0.3485^{* *}$ & $0.2922 * *$ & -0.0340 & -0.0013 & $0.1014^{*}$ & $-0.1412^{*}$ & & $0.3718^{* *}$ \\
\hline ForeignInv & 0.0869 & $0.2909^{* *}$ & -0.0761 & 0.0691 & -0.3046 & $0.1468^{*}$ & 0.0158 & 0.1941 ** & 0.0372 & -0.0218 & -0.0172 & -0.0527 & $0.3702 * *$ & \\
\hline $\begin{array}{l}\text { *,** Denote } S \\
\text { BoardInd= Du } \\
\text { ACInd =Dum! } \\
\text { IAF=Dummy } \\
\text { BoardMeet= T } \\
\text { AC Size= Nun } \\
\text { AC TimeCom } \\
\text { Big4= A dum! } \\
\text { ConcOwner= } \\
\text { ForeignInv= D } \\
\text { Assets= The n } \\
\text { Leverage= To } \\
\text { Sgrowth= One } \\
\text { ROA= Return } \\
\text { Loss= Dummy }\end{array}$ & $\begin{array}{l}\text { variable take } \\
\text { he number } \\
\text { nber of direc } \\
=\text { A dummy } \\
\text { ny variable } \\
\text { Percentage o } \\
\text { ummy varia } \\
\text { atural log of } \\
\text { tal debt divic } \\
\text { year sales g } \\
\text { on Asset }\end{array}$ & $\begin{array}{l}\text { s the value } \\
\text { f board me } \\
\text { tors assigne } \\
\text { variable wh } \\
\text { which takes } \\
\text { o shares hel } \\
\text { ble takes th } \\
\text { total assets } \\
\text { led by total } \\
\text { rowth }\end{array}$ & $\begin{array}{l}\text { of } 1 \text { if the comp } \\
\text { tings held annu } \\
d \text { to the Commi } \\
\text { ich takes the va } \\
\text { the value of } 1 \text { i } \\
d \text { by the largest } \\
\text { value of } 1 \text { if } c \\
\text { assets }\end{array}$ & $\begin{array}{l}\text { llly by the } \\
\text { tee } \\
\text { ue of } 0 \text { if at } \\
\text { the firm } i \\
\text { hree substa } \\
\text { mpany has }\end{array}$ & $\begin{array}{l}\text { east one com } \\
\text { audited by or } \\
\text { tial sharehol } \\
\text { nstitutional } f \\
\text { fard of direct }\end{array}$ & $\begin{array}{l}\text { is } \\
\text { nittee mem } \\
\text { of the Big } \\
\text { rs. } \\
\text { eign invest } \\
\end{array}$ & $\begin{array}{l}\text {, otherwis } \\
\text { Auditing } \\
\text {, } 0 \text { otherw }\end{array}$ & $\begin{array}{l}\text { other com } \\
\text { irm in year }\end{array}$ & $\begin{array}{l}\text { ee for firm } \\
\text { herwise } 0\end{array}$ & vear & vise 1. & & & \\
\hline
\end{tabular}

Table 4 illustrates the correlation coefficients between the variables. Pair-wise correlation between two variables lower than 0.80 is not assumed to be a problem that threatens the regression analysis (Gujarati, 2004). Relatively 
high correlation between two independent variables (60 percent between the BoardInd and ACInd) and two control variables (78 percent between $R O A$ and Loss) is ignored and they are used in the same model to avoid the correlated omitted variable bias associated with a combination of variables.

The study provides separate regression tests on the full- and sub-samples of family-owned and non-family-owned firms for model 1 . This is because it has been suggested that regression tests made seperately on two groups may give better results when the relationship between the independent and dependent variables is hypothesized to be contingent on the moderator variable — in this case, family ownership (Staw and Oldham, 1978; Wright, Ferris, Sarin, \& Awasthi, 1996).

Table 5. Regression Results of Model 1 and Model 2

\begin{tabular}{|c|c|c|c|c|c|c|c|c|c|}
\hline \multicolumn{8}{|c|}{ Panel A: Regression Results of Model 1} & \multirow{2}{*}{\multicolumn{2}{|c|}{$\begin{array}{l}\text { Panel B: Regression } \\
\text { results of Model } 2\end{array}$}} \\
\hline & & \multicolumn{2}{|c|}{ Full Sample } & \multicolumn{2}{|c|}{ Family Owned } & \multicolumn{2}{|c|}{ Not Family Owned } & & \\
\hline & Expected & Coefficient & t-stat & Coefficient & t-stat & Coefficient & t-stat & Coefficient & t-stat \\
\hline PFamilyFirm & & & & & & & & -0.5463 & $-4.16 * * *$ \\
\hline BoardInd & - & -0.0428 & $-2.69 * * *$ & -.0 .1435 & -0.59 & -0.0316 & $-2.07 * *$ & -0.2531 & $-3.03 * * *$ \\
\hline ACInd & - & 0.0105 & 0.41 & -0.0449 & -0.70 & 0.0288 & $1.67 *$ & 0.0279 & 0.33 \\
\hline$I A F$ & - & -0.0192 & $-2.04 * * *$ & -0.0343 & -1.37 & -0.0175 & $-2.10 * *$ & 0.0308 & 0.82 \\
\hline PFamilyFirm* & & & & & & & & 0.5162 & $2.55 * *$ \\
\hline PFamilyFirm* & & & & & & & & -0.0569 & -0.28 \\
\hline PFamilyFirm* & & & & & & & & -0.1249 & -1.39 \\
\hline Board Meet & - & -0.0005 & $-1.77^{*}$ & -0.0010 & $-1.88^{*}$ & -0.0007 & $-1.75^{*}$ & -0.0002 & -0.92 \\
\hline AC Size & - & 0.0028 & 0.32 & 0.0085 & 0.58 & 0.0004 & 0.04 & 0.0009 & 0.11 \\
\hline AC TimeCom & - & 0.0169 & 1.07 & 0.0323 & 1.08 & 0.01103 & 0.61 & 0.0195 & 1.20 \\
\hline Big4 & - & 0.0136 & 1.27 & 0.0315 & 1.55 & -0.0001 & -0.01 & 0.0116 & 0.277 \\
\hline ConcOwner & - & -0.0487 & -1.20 & 0.0293 & 0.28 & -0.0937 & $-2.99 * * *$ & -0.0391 & -0.90 \\
\hline ForeignInv & - & 0.0084 & -0.64 & -0.0260 & -1.07 & 0.0084 & 0.62 & 0.0021 & 0.16 \\
\hline Assets & $?$ & 0.0022 & 0.66 & 0.0040 & 0.76 & 0.0076 & 1.86 & 0.0177 & $2.53 * *$ \\
\hline Leverage & + & 0.0160 & $2.01 * *$ & 0.0188 & 0.92 & 0.0005 & 0.03 & 0.0438 & $3.10 * * *$ \\
\hline Sgrowth & + & 0.0002 & 0.88 & 0.0002 & 0.82 & 0.0000 & 1.17 & 0.0002 & 0.89 \\
\hline$R O A$ & - & -0.1108 & -1.02 & 0.2220 & $2.74 * * *$ & -0.2137 & $-3.74 * * *$ & -0.0852 & -1.16 \\
\hline Loss & + & -0.0077 & -0.35 & 0.0643 & $2.78 * * *$ & -0.0030 & $-1.93 * *$ & 0.0082 & 0.50 \\
\hline Prob $>C h i^{2}$ & & 0.0000 & & 0.0000 & & 0.0000 & & 0.0000 & \\
\hline$R^{2}$ (between) & & 0.3536 & & 0.3497 & & 0.4071 & & 0.3660 & \\
\hline
\end{tabular}

The reported t-statistics are robust values to control for heteroskedasticity. ${ }^{*}, * *, * * *$ Denote Significance at the $0.1,0.05$ and 0.001 level respectively.

PFamilyFirm= Predicted value of regressing family ownership on the natural log of total assets and ROA.

BoardInd $=$ Dummy variable takes the value of 1 if Board of Directors is comprised of a majority of non-executives, otherwise 0 ACInd =Dummy variable which takes the value of 1 if the committee is comprised of a majority of non executive directors, otherwise 0 .

IAF=Dummy variable takes the value of 1 if the company has a separate internal audit function, otherwise 0 .

PFamilyFirm* BoardInd= Interaction term between PfamilyFirm and BoardInd variables.

PFamilyFirm* ACInd= Interaction term between PfamilyFirm and ACInd variables

PFamilyFirm* IAF= Interaction term between PfamilyFirm and IAF variables

BoardMeet $=$ The number of board meetings held annually by the board of directors

$\mathrm{AC}$ Size $=$ Number of directors assigned to the Committee

$\mathrm{AC}$ TimeCom= A dummy variable which takes the value of 0 if at least one committee member serve in another committee for firm $\mathrm{i}$ in year $\mathrm{t}$, otherwise 1 .

Big4= A dummy variable which takes the value of 1 if the firm $i$ is audited by one of the Big 4 Auditing Firm in year $t$, otherwise 0 . ConcOwner $=$ Percentage of shares held by the largest three substantial shareholders.

ForeignInv $=$ Dummy variable takes the value of 1 if company has institutional foreign investor, 0 otherwise.

Assets $=$ The natural log of total assets

Leverage $=$ Total debt divided by total assets Sgrowth $=$ One year sales growth

$\mathrm{ROA}=$ Return on Asset Loss= Dummy variable takes the value of 1 if net income is less than zero firm i in year $\mathrm{t}, 0$ otherwise. 
The regression results of model 1 are reported in panel A of table 5 . The results based on the full sample indicate that the coefficient for BoardInd is statistically significant and negative $(-0.0428 \mathrm{t}=-2.69)$, suggesting that firms which have independent boards are associated with lower discretionary accruals. This finding is consistent with the findings of Jaggi et al. (2009), Chtourou et al., (2001), Davidson et al., (2005), and Peasnell et al., (2005). The coefficient for BoardInd is also negative but insignificant $(-0.014 \mathrm{t}=-0.59)$ in the sub-sample of family-owned firms and negative and significant (-0.0316 $\mathrm{t}=-2.07)$ for the sub-sample of non-family-owned firms. These results are consistent with the findings of Jaggi et al. (2009) and Prencipe \& Bar-Yosef (2011). These findings validate hypothesis 2 that independent boards of directors are less effective at monitoring EM in family-owned firms compared to in non-family-owned firms. Consequently, although board members are formally independent in family-owned firms, they may be not independent in substance because of implicit ties to the controlling family.

Hypothesis 3 would be validated if the coefficient of ACInd was significant and negative for non-family-owned firms and insignificant or positive for family-owned firms. Inconsistent with the expectations, it is positive and insignificant for the full sample $(0.0105 \mathrm{t}=0.41)$. This is consistent with the findings of Chotorou et al. (2001), but inconsistent with the findings of Xie et al. (2003) and Chang and Sun (2010), who find a significant negative relationship. The coefficient of $A C I n d$ is negative and insignificant for sub-sample of family-owned firms (-.0.449 $\mathrm{t}=-0.70)$ and positive and significant for non-family-owned firms $(0.0288 \mathrm{t}=1.67)$. These findings do not support hypothesis 3 that independent audit committees are less effective at monitoring EM in family-owned firms compared to in non-family-owned firms. These findings are inconsistent with those of Jaggi and Leung (2007) which suggest that the presence of audit committees is effective in constraining managerial EM behavior when no family members are present on corporate board.

As expected, the coefficient of $I A F$ is negative and significant $(-0.0192 \mathrm{t}=-2.04)$ for the full sample. This suggests that the presence of a separate internal audit function is effective in reducing EM made through accruals in Turkish firms. The findings of regressions on sub-samples validate hypothesis 4 that the presence of an IAF is negatively related to the level of EM in non-family-owned firms, but is unrelated to the level of EM in family-owned firms. The coefficient of $I A F$ is negative and insignificant for family-owned firms $(-0.0343 \mathrm{t}=-1.37)$ and negative and significant for non-family-owned firms $(-0.0175 \mathrm{t}=-2.10)$.

The results for the control variables show that the coefficient of BoardMeet is significant and negative for all samples. However, contrary to expectations, the coefficient is higher for family-owned firms $(-0.0010 \mathrm{t}=-1.88)$ compared to non-family-owned firms $(-0.0007 \mathrm{t}=-1.75)$, suggesting that regular meetings of the board are more effective at reducing EM in family-owned firms. The coefficient of ConcOwner is only negative and significant $(-0.0937 \mathrm{t}=-2.99)$ for non-family-owned firms. One possible explanation for this finding may be that the concentrated owners of family-owned firms are family members, and a conflict may occur between their self-interest and the motives of concentrated ownership in monitoring the behavior of managers. On the other hand, in non-family-owned firms, concentrated owners are more motivated than minority shareholders to control managerial behavior. The coefficient of Big4 is insignificant for all samples, and this is inconsistent with the findings of Karacaer and Özek (2010), who find a significant negative relationship between external auditor size and the level of abnormal accruals in Turkish firms.

The effects of ROA and Loss on EM are mixed for family-owned firms and non-family-owned firms alike. Unexpectedly, the coefficient of $R O A$ is positive and significant for family-owned firms $(0.2220 \mathrm{t}=2.74)$ but is, as expected, negative and significant for non-family-owned firms $(-0.2137 \mathrm{t}=-3.74)$. Loss is positive and significant for family-owned firms $(0.0643 \mathrm{t}=2.78)$ as expected, but negative and significant for non-family-owned firms $(-0.0030$ $\mathrm{t}=-1.93)$. The coefficient of Assets is positive and insignificant for all samples. Although it is insignificant, the positive sign implies that big firms with a high chance of receiving political attention are more likely to manipulate accounting numbers to avoid political scrutiny, consistent with the findings of Dechow and Dichev (2002), Chtourou and Bedard (2001), and Prawitt et al. (2009).

Additionally, the impact of family ownership control on the association between abnormal accruals and independent variables was examined by including interaction variables between PFamilyFirm and independent variables.

ABSAbbAcc $_{i t}=\beta_{0}+\beta_{1}$ PFamilyFirm $_{\mathrm{it}}+\beta_{2}$ BoardInd $_{\mathrm{it}}+\beta_{3}$ ACInd $_{\mathrm{it}}+\beta_{4}$ IAF $_{\mathrm{it}}+\beta_{5}$ PFamilyFirm $_{\mathrm{it}}$ PoardInd $_{\mathrm{it}}+\beta_{6}$ PFamilyFirm $_{\mathrm{it}}{ }^{*}$ ACInd $_{\mathrm{it}}+\beta_{7}$ PFamilyFirm $_{\mathrm{it}}$ PIAF $_{\mathrm{it}}+\beta_{8}$ BoardMeet $_{\mathrm{it}}+\beta_{9}$ ACTimeCom $_{\mathrm{it}}+\beta_{10}$ ACSize $_{\mathrm{it}}+\beta_{11}$ Big4 $_{\mathrm{it}}+\beta_{12}$ Assets $_{i t}+\beta_{13}$ Leverage $_{i t}+\beta_{14}$ SGrowth $_{i t}+\beta_{15}$ ROA $_{i t}+\beta_{16}$ Loss $_{\mathrm{it}}+\beta_{17}$ ConcOwner $_{\mathrm{it}}+\beta_{18}$ ForeignInv $_{\mathrm{it}}+\varepsilon$ (Model 2) (4)

The results of model 2 are reported in panel B of table 5. The coefficient of BoardInd is significantly negative $(-0.2531, \mathrm{t}=-3.03)$ and the interaction term on PFamilyFirm * BoardInd is positive and statistically significant $(0.5162$, $\mathrm{t}=2.55$ ). These results are consistent with hypothesis 2 , showing that family-ownership control moderates the 
monitoring effectiveness of independent boards. The coefficient of IAF and interaction term between FamilyFirm and $I A F$ are both insignificant and do not validate hypothesis.

\section{Conclusions and Limitations}

This paper has evaluated the moderating effect of family ownership on the relationship between the independent variables of board independence, audit committee independence and presence of internal audit function and the dependent variable of abnormal accruals. Overall, the findings provide evidence that family ownership in listed Turkish firms moderates the monitoring effectiveness of independent boards, proxied by a majority of non-executive directors on the board, and the monitoring effectiveness of an internal audit function.

This research has some limitations which should be considered when interpreting its research findings. Firstly, there is its sample selection bias; the selection of the study sample was based on a predetermined criterion, and so was non-random. However, because there are only a limited number of firms that disclose comprehensive and relevant corporate governance information publicly, it is very difficult for corporate governance studies in Turkey to select firms randomly. Consequently, the limited sample size is another concern.

Another potential limitation may arise from the measurement of EM practices through the magnitude of abnormal accruals. Because accrual models make some assumptions when calculating the discretionary part of the total accruals, this may also affect the interpretation of the results.

Nevertheless, the results of this study may be used by stock market participants when evaluating the roles of internal corporate governance mechanisms in increasing the quality of reported earnings. The findings will also help regulators to define effective corporate governance attributes according to different institutional environments and to assess the requirements for disclosure of corporate governance practices.

To extend the current literature, further investigation of the quality of internal audit functions in family firms and the presence of real EM in family firms may be beneficial.

\section{Acknowledgements}

This paper is a significantly revised version of author's dissertation at the Business School of Marmara University, Turkey. Author thanks her dissertation committee. The author has also benefited from comments and discussions with Prof. Agnes Cheng from Louisiana State University, Yasemin Özerkek from Marmara University, Hüseyin Kaya and Bülent Anıl from Bahçeşehir University, conference participants at the EBES Conference (Rome).

\section{References}

Aharony, J., Wang, J., \& Yuan, H. (2010). Tunneling as an incentive for earnings management during the IPO process in China. Journal of Accounting and Public Policy 29(1),1-26. http://dx.doi.org/10.1016/j.jaccpubpol.2009.10.003

Ali, A., Chen, T.Y., Radhakrishnan. 2007. Corporate disclosures by family-ownership-controlled firms. Journal of Accounting and Economics, 44: 238-286. http://dx.doi.org/10.1016/j.jacceco.2007.01.006

Anderson, R.C., \& Reeb,D.M. (2003). Founding-family ownership and firm performance: Evidence from the S\&P 500, Journal of Finance, 58, 1301-1328. http://dx.doi.org/10.1111/1540-6261.00567

Anderson, R.C. \& Reeb, D.M. (2004). Board composition: balancing family influence in S\&P 500 firms. Administrative Science Quarterly, 49, 209-237.

Ankara Chamber of Industry. (2005). Aile Şirketleri Değişim ve süreklilik.

Bammens, Y., Voordeckers, W., \& Gils, A. V. (2011). Boards of Directors in Family Businesses. International Journal of Management, 13, 134-152.

Barnes, L.B., \& Hershon, S.A. (1976). Transferring power in the family business. Harvard Business Review. 54(4), 105-114.

Bartov, E. (1993). The timing of asset sales and earnings manipulation. The Accounting Review, 68(4), 840-855.

Bartov, E., Givoly, D., \& Hayn, C. (2000). The rewards to meeting or beating earnings expectations. SSRN Electronic Journal (March 1999). http://dx.doi.org/10.2139/ssrn.247435

Barua, A., Legoria, J., Moffitt, J.S. (2006). Accruals management to achieve earnings benchmarks: a comparison of pre-managed profit and loss firms, Journal of Business Finance \& Accounting, 33(5-6), 653-670. http://dx.doi.org/10.1111/j.1468-5957.2006.00017.x 
Baxter, P., \& Cotter, J. (2009). Audit committees and earnings quality. Accounting and Finance, 49, 267-290. http://dx.doi.org/10.1111/j.1467-629X.2008.00290.x

Beehr,T.,Drexler, J.A., \& Faulkner,S. (1997).Working in small family businesses: Empirical comparisons to non-family businesses, Journal of Organizational Behavior, 18(3), 297-312. http://dx.doi.org/10.1002/(SICI)1099-1379(199705)18:3<297::AID-JOB805>3.0.CO;2-D

Bergstresser, D., \& Philippon, T. (2006). CEO incentives and earnings management. Journal of Financial Economics, 80(3), 511-529. http://dx.doi.org/10.1016/j.jfineco.2004.10.011

Bhumik, S.K. \& Gregoriou, A. (2010). 'Family' ownership, tunnelling and earnings management: A review of the literature. Journal of Economic Surveys, 24 (4), 705-730. http://dx.doi.org/10.1111/j.1467-6419.2009.00608.x

Bradburry, M.E., Mak, Y.T., \& Tan S.M. (2006). Board characteristics, audit committee characteristics and abnormal accruals. Pacific Accounting Review, 18(2), 47-68. http://dx.doi.org/10.1108/01140580610732813

Burgstahler, D. \& Dichev. I. (1997), Earnings management to avoid earnings decreases and losses. Journal of Accounting and Economics, 24(1):99-126. http://dx.doi.org/10.1016/S0165-4101(97)00017-7

Burgstahler, D., \& Eames, M. (2006). Management of earnings and analysts' forecasts to achieve zero and small positive earnings surprises. Journal of Business Finance \& Accounting, 33(5-6), 633-652. http://dx.doi.org/10.1111/j.1468-5957.2006.00630.x

Carcello, J.V., Hollingsworth, C.W., Klein, A., \& Neal, T.L. (2006). Audit committee financial expertise, competing corporate governance mechanisms, and earnings management, Available at SSRN.

Carsrud, A.L. (1994). Meanderings of a resurrected psychologist or lessons learned in creating a program. Entrepreneurship, Theory, \& Practice. 19(1), 39-48.

Chang, J., \& Sun, H. (2010). Does the disclosure of corporate governance structures affect firms' earnings quality?. Review of Accounting and Finance. 9(3), 212-243. http://dx.doi.org/10.1108/14757701011068048

Chen, C.J. \& Jaggi, B. (2000). Association between independent non-executive directors, family control and financial disclosures in Hong Kong. Journal of Accounting and Public Policy, 19, 285-310. http://dx.doi.org/10.1016/S0278-4254(00)00015-6

Chen. K.Y., K.L. Lin, J. Zhou. (2005). Audit Quality and Earnings Management for Taiwan IPO Firms. Managerial Auditing Journal. 20(1):86-104. http://dx.doi.org/10.1108/02686900510570722

Cheng, Q., Warfield T.D. (2005). Equity incentives and earnings management. The Accounting Review, 80(2), 441-476. http://dx.doi.org/10.2308/accr.2005.80.2.441

Choi, Y., \& Lin, S. (2006). The market premium to meeting or beating analysts' forecasts: further evidence from the UK. Manchester Business School Working Paper No. 509, 1-25.

Chrisman, J.J.,Chua, J.H. , \& Sharma, P. (2005). Trends and directions in the development of a strategic management theory of the family firm. Entrepreneurship, Theory and Practice, 555-575. http://dx.doi.org/10.1111/j.1540-6520.2005.00098.x

Chtourou, S., Bedard M.J., \& Courteau L. (2001). Corporate governance and earnings management, Working Paper (University of Naval, Quebec).

Chua, J.H., Chrisman, J.J., \& Sharma, P. (1999). Defining the family business by behavior. Entrepreneurship Theory and Practice, 23, 19-39.

Cohen, D.A., \& Zarowin, P. (2010). Accrual-based and real earnings management activities around seasoned equity offerings. Journal of Accounting and Economics, 50, 2-19. http://dx.doi.org/10.1016/j.jacceco.2010.01.002

Corbetta, G. (1995). Patterns of development of family businesses in Italy. Family Business Review, 8(4), 255-265. http://dx.doi.org/10.1111/j.1741-6248.1995.00255.x

Daily, C.M. \& Dollinger, M.J. (1992). An empirical examination of ownership structure in family and professionally-managed firms. Family Business Review, 5, 117-136. http://dx.doi.org/10.1111/j.1741-6248.1992.00117.x

Davidson, R., Goodwin-Stewart, J., \& Kent, P. (2005). Internal governance structures and earnings management. Accounting and Finance, 45, 241-267. http://dx.doi.org/10.1111/j.1467-629x.2004.00132.x 
Dechow, P.M., Sloan, R.G., \& Sweeney, A.P. (1995). Detecting earnings management. The Accounting Review, 70(2), 193-225.

Dechow, P.M., Dichev I.D. (2002). The quality of accruals and earnings: The role of accrual estimation errors.

DeFond, M.L., \& Jiambalvo, J. (1994). Debt covenant violation and manipulation of accruals. Journal of Accounting and Economics. 17, 145-176. http://dx.doi.org/10.1016/0165-4101(94)90008-6

Demirag, I., \& Serter, M. (2003). Ownership patterns and control in Turkish listed companies. Corporate Governance. 11(1), 40-51. http://dx.doi.org/10.1111/1467-8683.00300

Fan, J.P.H. \& Wong, T.J. (2002). Corporate ownership structure and the informativeness of accounting earnings in East Asia. Journal of Accounting and Economics 33: 401-425. http://dx.doi.org/10.1016/S0165-4101(02)00047-2

Felo, A.J., Krishnamurthy, S., \& Solieri, S.A. (2003). Audit committee characteristics and perceived quality of financial reporting. Available at SSRN. http://dx.doi.org/10.2139/ssrn.401240

Friedlan, J.M. (1994). Accounting choices of issuers of initial public offerings. Contemporary Accounting Research, 11(1), 1-31. http://dx.doi.org/10.1111/j.1911-3846.1994.tb00434.x

Gallo, G. A., Tapies, J., \& Cappuyns, K. (2000). Comparison of family and non-family business: Financial logic and personal preferences. "Chair of Family Business" IESE Research Paper No. 406, BIS. University of Navarra.271

Gallo, M.A., \& Sveen, J. (1991). Internationalizing the family business, facilitating and restraining factors. Family Business Review. 42(2), 181-190. http://dx.doi.org/10.1111/j.1741-6248.1991.00181.x

Gomez-Mejia, L., Nuñez-Nickel, M., \& Gutierrez, I. (2001). The role of family ties in agency contracts. Academy of Management Journal, 44, 81-95. http://dx.doi.org/10.2307/3069338

Guidry, F., Leone, A. J., \& Rock, S. (1999). Earnings-based bonus plans and earnings management by business-unit managers. Journal of Accounting and Economics, 26(1-3), pp. 113-142. http://dx.doi.org/10.1016/S0165-4101(98)00037-8

Gujarati. (2004). Basic econometrics. The McGraw-Hill Companies, 2nd Edition.

Healy, P.M. (1985). The effect of bonus schemes on accounting decision. Journal of Accounting and Economics, 7 , 85-107. http://dx.doi.org/10.1016/0165-4101(85)90029-1

Holthausen, R., Larcker, D. \& Sloan, R. (1995). Annual bonus schemes and the manipulation of earnings. Journal of Accounting and Economics, 19, 29-74. http://dx.doi.org/10.1016/0165-4101(94)00376-G

Iatridis, G., \& Kadorinis, G. (2009). Earnings management and firm financial motives: a financial investigation of UK listed firms. International Review of Financial Analysis, 18(4), 164-173. http://dx.doi.org/10.1016/j.irfa.2009.06.001

Institute of Internal Auditors (IIA). (2005). Corporate governance. The Institute of Internal Auditors Homepage. Available at http://www.theiia.org/?doc_id $=1041$.

Jackson, S., Wilcox, W., \& Strong, J. (2002). Do initial public offering firms understate the allowance for bad debts? Advances in Accounting, 19, 89-118. http://dx.doi.org/10.1016/S0882-6110(02)19006-7

Jaggi, B., Leung, S. (2007). Impact of family dominance on monitoring of earnings management by audit committees: Evidence from Hong Kong. Journal of International Accounting, Auditing and Taxation, 16: 27-50. http://dx.doi.org/10.1016/j.intaccaudtax.2007.01.003

Jaggi, B., Leung, S., Gul, F. (2009). Family control, board independence and earnings management: Evidence based on Hong Kong firms. Journal of Accounting and Public Policy, 28, 281-300. http://dx.doi.org/10.1016/j.jaccpubpol.2009.06.002

Jensen, M.C., \& Meckling, W.H. (1976). Theory of the firm: managerial behavior, agency costs and ownership structure. Journal of Financial Economics, 3(4), 305-360. http://dx.doi.org/10.1016/0304-405X(76)90026-X

Jeong, S.W., \& Rho, J. (2004). Big six auditors and audit quality: the Korean evidence. The International Journal of Accounting, 39, 175-196. http://dx.doi.org/10.1016/j.intacc.2004.02.001 
Jiang, W, Lee P., \& Anandarajan A. (2008). The association between corporate governance and earnings quality: further evidence using the Gov-Score. Advances in Accounting, Incorporating Advances in International Accounting. 24, 191-201.

Jiraporn, P., Dadalt, P. (2007). Does founding family control affect earnings management? An empirical note. Working paper, SSRN abstract_id=1017856.

Karacaer, S., Özek, P. (2010). The relationship between the audit firm and earnings management?: An empirical study in Istanbul Stock Exchange. The Journal of Accounting and Finance.48, 60-74.

Kasznik, R. (1999). On the association between voluntary disclosure and earnings management. Journal of Accounting Research, 37, 57-81. http://dx.doi.org/10.2307/2491396

Kasznik, R., \& McNichols, M. (2002). Expectations matter? Evidence from analyst forecast revisions and share prices. Journal of Accounting Research, 40(3), 727-759. http://dx.doi.org/10.1111/1475-679X.00069

Klein, A. (2002). Audit committee, board of director characteristics, and earnings management. Available at http://papers.ssrn.com/paper.taf?abstract_id $=246674$.

Klein, P., Shapiro, D., \& Young, J. (2005). Corporate governance, family ownership and firm value : the Canadian evidence. Corporate Governance, 13(6), 769-784. http://dx.doi.org/10.1111/j.1467-8683.2005.00469.x

Kothari, S.P., Leone, A.J., \& Wasley, C.E. (2005). Performance adjusted discretionary accrual measures. Journal of Accounting and Economics, 39, 163-197. http://dx.doi.org/10.1016/j.jacceco.2004.11.002

La Porta, R., Lopez-de-Silanes, F., Shleifer, A. \& Vishny, R. (1998). Law and Finance. Journal of Political Economy, 106, 1113-1155. http://dx.doi.org/10.1086/250042

Larcker, D. F., Richardson S. A., \& Tuna I. (2007). Corporate governance, accounting outcomes, and organizational performance. The Accounting Review, 82(4), 963-1008. http://dx.doi.org/10.2308/accr.2007.82.4.963

Lee, J. (2006). Family firm performance: further evidence. Family Business Review, 19, 103-114. http://dx.doi.org/10.1111/j.1741-6248.2006.00060.x

Matsumoto, D.A. (2002). Management's incentives to avoid negative earnings surprises. The Accounting Review, 77(3), 483-514. http://dx.doi.org/10.2308/accr.2002.77.3.483

Matsunaga, S.R., \& Park, C.W. (2001). The effect of missing quarterly earnings benchmark on the CEO's annual bonus. The Accounting Review, 76(3), 313-332. http://dx.doi.org/10.2308/accr.2001.76.3.313

Mitton, T. (2002). A cross-firm analysis of the impact of corporate governance on the East Asian financial crisis. Journal of Financial Economics, 64, 215-241. http://dx.doi.org/10.1016/S0304-405X(02)00076-4

Osma, B.G., \& Naguer, B.G.A. (2007). The effect of the board composition and its monitoring committees on earnings management: evidence from Spain. Corporate Governance, 15(6), 1413-1428. http://dx.doi.org/10.1111/j.1467-8683.2007.00654.x

Park, Y.W., \& Shin, H.H. (2004). Board composition and earnings management in Canada. Journal of Corporate Finance, 10, 431-457. http://dx.doi.org/10.1016/S0929-1199(03)00025-7

Peasnell, K.V., Pope, P.F., \& Young, S. (2005). Board monitoring and earnings management: do outside directors influence abnormal accruals? Journal of Business Finance \& Accounting. 32(7-8), 1311-1346. http://dx.doi.org/10.1111/j.0306-686X.2005.00630.x

Piot, C., \& Janin, R. (2007). External auditors, audit committees and earnings management in France. European Accounting Review, 16(2):429-454. http://dx.doi.org/10.1080/09638180701391030

Prawitt, D.F., Smith, J.L., \& Wood, D.A. (2009). Internal audit quality and earnings management. The Accounting Review, 84(4), 1255-1280. http://dx.doi.org/10.2308/accr.2009.84.4.1255

Prencipe, A., Markarian, G. \& Pozza, L. (2008). Earnings management in family-ownership-controlled firms: evidence from R\&D cost capitalization in Italy. Family Business Review, 21 (1), 71-88. http://dx.doi.org/10.1111/j.1741-6248.2007.00112.x

Prencipe, A., Bar-Yosef, S. (2011). Corporate governance and earnings management in family-controlled companies. Journal of Accounting, Auditing\& Finance, 26, 199-227. http://dx.doi.org/10.1177/0148558X11401212

Rusmin, R. (2010). Auditor quality and earnings management: Singaporean evidence. Managerial Auditing Journal, 25(79), 618-638. http://dx.doi.org/10.1108/02686901011061324 
Saleh, N.M., Iskandar, T.M., \& Rahmat, M.M. (2007). Audit committee characteristics and earnings management: evidence from Malaysia. Asian Review of Accounting, 15(2), 147-163. http://dx.doi.org/10.1108/13217340710823369

Schulze, W.S., Lubatkin, M. H., \& Dino, R.N. (2002). Altruism, agency, and the competitiveness of family-ownership-controlled firms. Managerial and Decision Economics, 259, 247-259. http://dx.doi.org/10.1002/mde.1064

Scott. W.R., (2006). Financial accounting theory. Fourth Edition. Pearson Prentice Hall.

Shivakumar, L. (2000). Do firms mislead investors by overstating earnings before seasoned equity offerings? Journal of Accounting and Economics, 29, 339-371. http://dx.doi.org/10.1016/S0165-4101(00)00026-4

Shuto, A. (2007). Executive compensation and earnings management: empirical evidence from japan. Journal of International Accounting, Auditing and Taxation, 16. http://dx.doi.org/10.1016/j.intaccaudtax.2007.01.004

Siebels, J.-F. \& Knyphausen-Aufseb, D. (2011). A review of theory in family business research: the implications for corporate governance, International Journal of Management Review. 1-25.

Siregar, S.V., \& Utama, S. (2008). Type of earnings management and the effect of ownership structure, firm size, and corporate-governance practices: evidence from Indonesia. The International Journal of Accounting. 43, 1-27. http://dx.doi.org/10.1016/j.intacc.2008.01.001

Song, J., Windram, B. (2004). Benchmarking audit committee effectiveness in financial reporting. International Journal of Auditing, 8, 195-205. http://dx.doi.org/10.1111/j.1099-1123.2004.00090.x

Staw, B.M., Oldham, G., (1978). Reconsidering our dependent variables - A critique and empirical study. Academy of Management Journal, 21, 539-559. http://dx.doi.org/10.2307/255699

Sweeney, A.P. (1994). Debt-covenant violations and managers' accounting responses. Journal of Accounting and Economics, 17(3), 281-308. http://dx.doi.org/10.1016/0165-4101(94)90030-2

Teoh, S.H., Welch, I., \& Wong, T.J. (1998a). Earnings management and the long-run market performance of initial public offerings. The Journal of Finance, 53(6), 1935-1974. http://dx.doi.org/10.1111/0022-1082.00079

Teoh, S.H., Welch, I., \& Wong, T.J. (1998b). Earnings management and the underperformance of seasoned equity offerings. Journal of Financial Economics, 50, 63-99. http://dx.doi.org/10.1016/S0304-405X(98)00032-4

Yurtoglu, B.B. (2003). Corporate governance and implications for minority shareholders in Turkey. Turkish Economic Association Discussion Paper.1-30.

Villalonga, B., \& Amit, R. (2004). How do family ownership, control, and management affect firm value. Harvard Business School and Wharton School, University of Pennsylvania.

Wang, D. (2006). Founding Family Ownership and Earnings Quality. The Accounting Review. 44, 619-656.

Wright, P., Ferris, S., Sarin, A., Awasthi, V., (1996). Impact of corporate insider, blockholder, and institutional equity ownership on firm risk taking. Academy of Management Journal 39 (2), 441-463. http://dx.doi.org/10.2307/256787

Xie, B., Davidson W., \& DaDalt P. (2003). Earnings management and corporate governance: the roles of the board and the audit committee. Journal of Corporate Finance, 9 (3), 295-317. http://dx.doi.org/10.1016/S0929-1199(02)00006-8

\section{Notes}

Note 1. Although, as in many emerging markets, the number and size of the joint stock companies have continued to increase, Turkey has an underdeveloped equity culture. Market capitalization of Turkey as a percentage of GDP was around 16 percent, 38 percent and 40 percent for the years 2008, 2009 and 2010 respectively (Bulletin of the Capital Markets Board of Turkey, 2010), significantly below the OECD averages of 60 percent, 83 percent, and 90 percent for those years respectively (http://www.indexmundi.com/facts/oecd-members/market-capitalization-of-listed-companies, 2011) .

Note 2. During the period under analysis, the old Turkish commercial law was in force. The new commercial law became effective on 1 July, 2012, and also permits issuing non-voting shares and shares which have an arbitrarily high number of votes. 